\title{
Insurgency, Authoritarianism, and Drug Trafficking in Mexico's "Democratization"
}

José Luis Velasco 


\section{INSURGENCY, AUTHORITARIANISM, AND \\ Drug TrafFicking IN MEXICO'S \\ "DEMOCRATIZATION"}

José Luis Velasco

Routledge

New York \& London 
Published in 2005 by

Routledge

270 Madison Avenue

New York, NY 10016

www.routledge-ny.com

Published in Great Britain by

Routledge

2 Park Square

Milton Park, Abingdon

Oxon OX14 4RN

www.routledge.co.uk

Copyright $(1) 2005$ by Taylor \& Francis Group, a Division of T\&F Informa.

Routledge is an imprint of the Taylor \& Francis Group.

Printed in the United States of America on acid-free paper.

All rights reserved. No part of this book may be reprinted or reproduced or utilized in any form or by any electronic, mechanical, or other means, now known or hereafter invented, including photocopying and recording, or in any information storage or retrieval system, without permission in writing from the publishers.

$\begin{array}{lllllllllll}10 & 9 & 8 & 7 & 6 & 5 & 4 & 3 & 2 & 1\end{array}$

Library of Congress Cataloging-in-Publication Data

Library of Congress Cataloging-in-Publication Data

Velasco, Jose Luis, 1970-

Insurgency, authoritarianism, and drug trafficking in Mexico's

"democratization" / by Jose Luis Velasco.

p. cm. -- (Latin American studies)

Includes bibliographical references and index.

ISBN 0-415-97209-4 (hardback : alk. paper)

1. Mexico--Politics and government--1988- 2.

Democracy--Mexico--History--20th century. 3.

Insurgency--Mexico--History--20th century. 4.

Authoritarianism--Mexico--History--20th century. 5. Drug

traffic--Mexico--History--20th century. I. Title.

II. Series: Latin American studies (Routledge (Firm)) 


\section{Contents}

List of Tables vii

List of Figures $\quad$ ix

List of Abbreviations and Acronyms xi

Acknowledgments $\quad x v$

Chapter One

Anomalies of Mexico's Democratic Transition 1

Chapter Two

Democratic Transition in Mexico 17

Chapter Three

Transition and Insurgency 25

Chapter Four

Authoritarian Structures and Practices $\quad 59$

Chapter Five

$\begin{array}{ll}\text { Transition and Illegal Drugs } & 89\end{array}$

Chapter Six

Beyond Democratic Transition: Toward a Redistributive Agenda

Appendix

Tables and Figures

Notes

Bibliography 203

Index 